Article

\title{
Keeping It Real: Decolonizing Christian Inter-Religious Practice as an Exercise in a Practical Theology of the Cross
}

\author{
Pamela R. McCarroll \\ Emmanuel College, Victoria University in the University of Toronto, 75 Queen's Park Crescent, Toronto, \\ ON M5S 1K7, Canada; pam.mccarroll@utoronto.ca
}

Received: 21 February 2019; Accepted: 12 March 2019; Published: 16 March 2019

\begin{abstract}
What is suffering? What is hope?" These are questions I have asked for years with classes full of students training for Christian ministry. Now, I ask these questions in classes with Buddhist, Muslim, Jewish, Christian, and 'spiritual but not religious' students, all in training to be spiritual care therapists. The institution where I serve is in the process of transitioning from a mono-religious Christian theological College to a centre for multi/inter-religious education. Those of us who teach in the program are disrupted continually by pedagogical challenges that both perplex and energize us. The multi-religious classroom decolonizes spaces long dominated by Christian theological discourse. Course content yields to a fluid and open-ended, interactive process. My "mastery of the field" gives way to an ongoing practice of surrender-a kenotic self-emptying — that usually leaves me shaken in overwhelming awe or angst-ridden questioning. Through a practical theological methodology that begins with lived human experience, this paper shares an autoethnographic account of my experience as a teacher in the multi-religious classroom. It presents key dimensions of the theology of the cross as an interpretive framework and closes by examining how the theology of the cross offers a practical Christian theological reflective process to empower decolonizing pedagogy.
\end{abstract}

Keywords: theology of the cross; inter-religious pedagogy; autoethnography; decolonizing practice; practical theology; theology and practice

\section{Introduction}

A handful of Christian theological schools in North America are in the process of transitioning from being institutions of mono-religious education and professional training to becoming multi-religious/inter-religious schools. ${ }^{1}$ My institution is in the process of this transition. While it is an exciting process that is expanding programs and, indeed, enabling institutional viability in a way that might not be possible otherwise, it is a process fraught with questions that challenge the legacies upon which the institutions are built, the normative pedagogical priorities and practices, and the whole enterprise of academic learning based on the European University with its colonizing impulses (Kwok 2005, pp. 186-208).

Unlike some of the other multi-religious theological institutions that have become fully inter-religious in their mission, vision, and values, my school identifies itself with its founding ecclesial body, a liberal Protestant Christian denomination ${ }^{2}$ with a tradition of leadership on issues

1 Some of these institutions include Claremont School of Theology, Hartford Theological Seminary, Harvard Divinity School, Union Theological Seminary, and Emmanuel College of Victoria University. Some of these began as Unitarian rather than Christian.

2 The United Church of Canada. 
of justice, inter-religious dialogue, trans/gender/sexuality advocacy, indigenous rights, etc. As such, the decision was made to begin offering programs in professional and academic degrees (spiritual care therapy and theological ${ }^{3}$ studies) with a Muslim and a Buddhist focus, as well as openness to hybrid programs for those interested in Jewish, Sikh, and other religious foci. For the sake of justice and equity, its inter-religious relationships, commitment to the Biblical notions of hospitality (Reynolds 2008, pp. 233-35), and its yearning to engage in transformative and contextually engaged education, my institution's move to develop multi-religious programs was a natural step. On the one hand, however, difficult questions began to emerge regarding the school's decision to maintain its Christian identity: In what ways does this set up a 'soft' colonialism whereby non-Christian traditions and identities are "othered" and ultimately colonized? In a recent chapter, my colleagues and I ask some other similar questions:

Do we reproduce the experience of [soft colonialism that our] Christian Indigenous students [complained about] with Muslim, Buddhist, and occasional Jewish, Hindu, or Sikh students? Can a Christian school "host" other religions without perpetuating colonialism? Or, in the search for justice and equity, do we need to develop a fully interreligious ethos as our institutional mission? (Couture et al. 2019, p. 169)

On the other hand, without appealing to a larger universalizing conception of religions, which itself is a colonizing act (Welch 2012, p. 353ff), if our institution is not grounded in a particular religious tradition and practice, how can it be a place where particularities of faith practices, communities, and beliefs are taken seriously? ${ }^{4}$ (Boff 1998, p. 2)

Through a practical theological methodology that begins with lived human experience, this paper presents an autoethnographic account (Moschella 2018, pp. 5-29; Wall 2008) of my experience as a teacher in a multi-religious course, Suffering and Hope, and reflects on the experience through the theology of the cross as it seeks to reclaim this "thin tradition" (Hall 2003, pp. 13-14; 2012, p. 79) as a resource for Christian decolonizing practices within multi-religious settings. First, I briefly situate the program, myself, and the course. Second, I share an autoethnographic account of my experience teaching the class, including journal entries following two critical incidents. Third, I outline the theology of the cross as an interpretive framework through both critical and constructive processes. Finally, I present the theology of the cross as a practical theological reflective process for transforming and decolonizing pedagogy. I conclude by raising some challenges while also claiming the potential of a practical theology of the cross to support Christian participation in decolonizing practices.

Prior to moving into the body of the paper I wish to acknowledge some of the issues and challenges of using autoethnography as part of my methodology. Autoethnography can be helpful for unpacking critical incidents that carry deeper meaning than is immediately evident. It allows an author to use their own lived experience as the topic of study and invites reflective hermeneutical analysis in the hope that, through the interpretive process, new knowledge will emerge both for the author and for the reader. In that sense, then, there is an inductive quality to the methodology, which anticipates new knowledge emerging through the writing and interpretive process. At the same time, however, there is an obvious and deep reflexivity, wherein the author not only creates the narrative but also brings an interpretive lens to the narrative. It is an organic and dialogical methodology. Indeed, because the subject is also the researcher, it is not possible to bracket subjectivity, as is common in some qualitative research practices. In fact, this is a quality that is lauded by proponents of the methodology because, they argue, it is honest about the role of subjectivity in research. Critics of the methodology argue that it is too subjective to truly offer new knowledge. One final comment regarding ethical

3 I use "theology" and "theological" throughout, recognizing that this language is appropriate for theistic traditions such as Judaism, Islam, and Christianity, but is not appropriate for non-theistic traditions, including dominant traditions within Buddhism.

4 Boff refers to "the givenness of faith" as a primary aspect of theology in general. 
practice in relation to my use of autoethnography: While I have shared honestly about my experience of the course, I have altered some details in my descriptions of students to ensure their anonymity and privacy.

\section{Situating the Program, Myself and the Course}

Those of us who teach in the multi-religious programs at my institution see amazing things happening among the students in the program and within our own teaching and relationships. We are continually disrupted by pedagogical challenges that both confound and excite us (Couture et al. 2019, p. 169). Given that examinations of power and privilege and post-colonial critiques are central elements of our programs, the complex tensions that can emerge within the diverse community are rather ubiquitous (Couture et al. 2019). In addition, as a theological college, priority is placed on lived religion, religious belonging, and expression of all faculty and students-a reality that further complicates and also enriches the dynamics. Unlike religious studies departments which have engaged in the study of religions at a distance, as an academic study of phenomena, there is an embedded reflexivity that is part of the theological enterprise whereby religious commitments, practices, communities, and traditions are central in the epistemology, methodology, and content of courses and curricula (Swinton and Mowat 2006, pp. v-vi). Such theological reflexivity invites students to bring the passion and grounding of their faith ${ }^{5}$ into the centre of their learning and conversations. This brings with it life-giving opportunities for learning and growth as well as complex challenges and tensions that constantly seek to up-end hidden ways in which colonizing impulses are at play.

I am a white, middle-aged, cis-gender, coupled, straight, able-bodied, educated, ordained, and protestant professor. I am also a registered psycho(-spiritual) therapist and certified as a Clinical Pastoral Education (CPE) Supervisor-Educator, having served for several years as head of the spiritual care department in a large teaching hospital. Relative to my larger societal and global context, I have much power and privilege-some aspects of which I am aware of and some of which I, no doubt, am not. Various experiences and relationships have imprinted my being with a mindfulness of vulnerability-my experiences of depression, divorce, multiple losses, and having struggled as a woman in a patriarchal church; my relationships working with dying people and those suffering trauma, with refugee claimants and communities of solidarity in El Salvador and with people in the foodbank system, among others. I bring this all to my teaching and to my research.

Prior to the beginning of the course, I was aware that it would represent a turning point, of sorts, in my journey as a teacher. For years I had taught a course on suffering and hope from within a Christian frame within an exclusively Christian theological school. Now I was teaching the course, Suffering and Hope: Multi-faith Perspectives for Spiritual Care, in a multi-religious context with a multi-religious focus. While I had worked with many students of diverse religious backgrounds in CPE and had taught several courses with a religiously diverse student body, this was the first time I was teaching on a topic that started with diverse religious practices and understandings of suffering and hope. I was nervous, especially when I saw the class list getting longer, filling up with names of students from all backgrounds. I chose to keep a journal to track my inner reflections and outer journey in the class, recognizing this as a critical juncture and seeking to learn what I could.

Most students in the course were enrolled in the Master of Pastoral Studies, Spiritual Care and Psychotherapy Certificate (MPS, SCP Cert.) program and in either the Buddhist, Christian, Muslim, or hybrid stream. ${ }^{6}$ Some questions that framed my goals for the course include the following:

5 While I recognize that 'faith' is a contested term in some inter-religious contexts, I use it here to connote the dynamic life-giving core of 'lived religion'.

6 Including those who identify with more than one tradition/practice and those who identify as Jewish, Sikh, and others. These students seek to serve in spiritual care/psycho-spiritual therapy in public and religious institutions, in healthcare, hospice, counselling centres, and private practice. Our program is designed for them to be equipped for professional designation with the Canadian Association for Spiritual Care (CASC) and the College of Registered Psychotherapists of Ontario (CRPO). 
How might students engage in directed reflection on their own lives and that of their communities, their religious traditions, and those of each other to develop perspectives on suffering and hope that support them "at the bedside" and in their spiritual and public leadership? How can they deepen their hermeneutics of suffering and hope to enable them to see multiple perspectives while also deepening their understanding within their own faith perspectives? How might students' practices of care and self-awareness be built up through the course?

\section{The Class-An Autoethnographic Account}

Walking into the classroom on the first day, I am struck by the vast intersectionality represented in the twenty-two bodies gathered together. As we introduce ourselves, the diversity becomes both clearer and more complex: Several older white women identifying as Buddhist, Christian, spiritual but not religious, lesbian, cis, straight, trans; several younger niqabi and hijabi women identifying as Muslim; a few kippah-wearing folk identifying as Jewish, Bu-Jewish, cis, and trans; a few middle-aged men, some in traditional clothing, identifying as Muslim Imams; a young Asian Canadian identifying as non-binary trans, Christian; a middle-age white woman identifying as "Hindu, mostly, and Christian;" and a couple of white older men, gay and straight, one in the garb of an ordained Buddhist monk. By the end of the first class, I feel the ground shifting beneath my feet.

Most classes open with a territorial acknowledgement ${ }^{7}$ read together by the students and with a spiritual practice led by various students. While I guide the first few classes and explore dimensions of suffering and hope in religious and social sciences literature focussed around specific case studies, several of the classes include guest speakers who consider our theme from different faith identities and locations. A local Jewish Rabbi explores the Shoah and how Jewish theology and practice engages questions of suffering and hope post-Shoah. An indigenous leader gathers us in a sharing circle and offers his reflections on the Truth and Reconciliation Commission (TRC) in Canada through his own family's story of residential schools, the multi-generational suffering that continues, and the marvel of resilience and hope in the midst of all that has happened. Our Muslim studies colleague shares conceptions of suffering and hope in Islam through the unjust suffering of blacks in America wrestling with understandings of suffering in the face of G-d's will and power. Our Buddhist studies colleague looks at suffering and liberation in Buddhism through narratives of people who have chosen assisted dying. I present understandings of G-d in the face of suffering through post-Christendom interpretations (Hall 2012, pp. 148-58; McCarroll 2014a, pp. 99-189), in light of atrocities committed in the name of Christianity, and in the face of narratives of personal loss (McCarroll 2014b).

During the semester, through our students, their families, and communities, the world's events are very much present in the classroom. Diverse reflections on suffering and hope engage events taking place in the world: Canada's passage of assisted dying legislation, Donald Trump's inauguration, the Women's March on Washington and Toronto and elsewhere, the Quebec Mosque massacre, the war in Syria, the famine in Somalia, the anti-Islamic and anti-Jewish graffiti and actions in Toronto and reported across Canada.

Questions of power and authority, particularity identity, coloniality, and decoloniality, are dominant themes throughout the course. The intra-religious question of power and authority asks who speaks for whom? Students consider how to trust the public representation of their own faith perspectives among the class and with visiting speakers of the different traditions. Trust is needed both to represent respective traditions in the class and to communicate the tradition(s) to a larger

7 As we come together in this place, we take a moment to acknowledge this sacred land on which our institution stands. This land has been a site of human activity for many thousands of years. This land is the territory of the Huron-Wendat and Petun First Nations, the Seneca, and, most recently, the Mississaugas of the Credit River. Today, the meeting place of Toronto is still the home to many Indigenous people from across Turtle Island. We are grateful for the opportunity to study, live, and work on this territory. Let us be mindful of broken covenants and strive to make right with all our relations. May peace be the way. 
diverse group. Notably, in the rendering of the various religious perspectives, the range of possibilities and multiplicity of each tradition are emphasized. Students who identify with particular religious groups locate themselves within the larger multiplicity of their own tradition, and other students intuitively seek to make links with their own religious commitments and practices. Through these classes, the intra-religious dimensions also point to the multi-religious identity of the class participants as well as to inter-religious connections between thought and practice.

As the teacher in the midst of this complexity, I face two primary critical incidents-experiences in which I found myself disoriented by my role and how to move forward given the vast complexity of the classroom, the topic, and student perspectives. My authority as a teacher, my mastery of the field, my common practices to synthesize and integrate student input into a larger whole, my own struggle to recognize and unearth colonizing impulses within me-all of these issues and more wrestle within me at various points throughout the semester. I share my journal entry from the first such incident.

\subsection{Journal Entry, Week $2^{8}$}

Nothing could have prepared me for class today. I asked them to come prepared to respond to two questions: "What is suffering? What is hope?" As the multiplicity of voices came forth they represented many opposing perspectives and widely divergent practices and understandings. How was I to engage this? I had been intellectually ready, but the lived experience, with me at the front of the classroom, brought shuddering to my chest and a tense pain in my gut.

Buddhist responses: "Hope is suffering, a cause of suffering - a perpetual attachment to that which can only cause suffering. I find it more helpful to think in terms of suffering and liberation rather than hope. It is all a state of mind. We must change our way of thinking about things and not get attached even to the idea of suffering." Pause. "But there is a sense that we have a kind of hope in the next life," another student pipes up, "like we hope to be on a higher level next time, though that can't be our reason for doing things, it is a kind of hope that is behind everything".

Muslim responses: "We don't really believe in suffering. It is all from God, so to think of it as suffering forgets it is God's will." "No," another student interjects, "we believe that suffering exists, but in some sense it is such a given in life we don't spend much time thinking about it except as a test or a means toward greater wholeness and peace. Every life includes suffering and struggle." Another adds, "suffering is truly a sign of God's favour."

Jewish responses: "Suffering calls us to protest against a world that allows such evil to prevail, to protest even against G-d who allows it to be." Another presses, "I don't agree, actually. It's important to find meaning in whatever happens. We need to take responsibility for the meaning we give things. Suffering is all about a loss of meaning, and hope comes when we take responsibility for ourselves, our actions, in spite of everything bad that may have happened."

Christian responses: "God suffers with the suffering. Like Jesus hanging on the cross with all who suffer. There is some glimmer hope in that, that we aren't alone." Another student interjects, "What about the real resurrection? And the second coming? That is the hope. We will be rewarded in the next life and when we suffer we can always remember that before long we will be with Jesus in paradise."

Spiritual-but-not-religious responses: "Well, I'm one of those people who kinda hangs between a few perspectives. Sometimes I hear people say, 'everything happens for a reason,' and I used to believe that. But I really wonder about that now. When I see some of the devastations in the world, I cannot seriously say that 'everything happens for a reason'. I think hope is in short supply these days,

8 Journal entries are italicized throughout the paper. 
and suffering definitely has the upper hand. But knowing that other people care, that one person's suffering affects others, there's something in that."

So how am I to do this, again? The layers and layers of disconnections and intersections are too great to synthesize, to integrate, to make sense of in any clear sort of way. No longer can I call upon the often-trod roads of Christian theology. No longer can I offer 'correctives' to theological content that jars my sensibilities. No longer can I use Western metanarratives to unpack what is happening. What am I to do with such plurality? Such shifting space? Such diversity? How can I teach when I am so aware of my own power and position? How can I teach when I'm aware of the history of violence done in the name of my religion? Where do I begin, again? These questions prod at me. "Just trust the process," the CPE Supervisor in my head whispers. "Rather," my theologian-self interjects, "trust the Spirit in the process." And my inner postcolonial teacher asks, "Am I allowed to think of Spirit here?" Okay, just trust. It's really all about trust anyway, isn't it?

To the class: "So, when you are at the bedside of someone who is clearly suffering, who says they are suffering and wants the suffering to stop and asks why, what do you do? Discuss that. And then explore together how what you do at the bedside connects with your beliefs or even practices of suffering and hope?"

The appeal to practice, to how things play out at the bedside of someone who is suffering, becomes the central framing question that animates and grounds my work with the students, both in the classroom and in feedback on papers. This question gives authority back to the students and allows them to ponder how it would really be for them as care givers and care receivers in the face of suffering. The question also shifts focus away from my need to manage and control the content of the class. Practices are changeable things, dependent on role, context, belief systems, and relationships. There's a fluidity, a shifting space, a vulnerability that cannot feign mastery or control in the face of suffering. The appeal to practice disrupts tidy ways of categorizing and standardizing normativity.

Throughout the course, my power as a professor as the one who evaluates and is ultimately accountable for the course bumps up against the particularity of my identity as a Christian practical theologian. When I mark papers, I am unable to draw on the authority of my role in ways I used to when I taught in a Christian context. Notions of normativity are suspect. Repeatedly, my own compulsion to frame a core of content or line of thought for the course are disrupted. I cannot escape intimations of complicity with colonial ways of being, as questions of authority, notions of what matters, and best practice are contested and up for grabs. Most notably, my class on Christian perspectives on suffering and hope marks a second critical incident for me in the semester.

\subsection{Journal Entry, Week 8}

Today was a killer! I was feeling so pumped about what I was going to share. Ridiculously, I realize, in the back of my mind I thought that the four different perspectives on suffering and hope I was sharing this week would be a nice culmination of all the different religious perspectives shared so far, since, for me, each of the four perspectives had been shaped by my interactions with Muslim, Jewish, and Buddhist thought. I honestly cannot believe my ignorance in all this - the implicit ways I was functioning out of a colonialist schema, almost like I wanted to tidy everything up with a nice Christian typology, of all things! My inability to see this in advance jars me.

As I shared Christian notions of suffering and hope with the class ... I became acutely aware of the many faces around the circle. How are they hearing what I am saying? How do they hear me as a teacher and as a person of faith? How can I be trustworthy? I feel the weightiness of Christendom's sin in the classroom even as I tell the post-Christendom narrative of the toppling of "God Almighty" (Hall 1993, pp. 92-129; Kwok 2005, pp. 1-20). Trying to find my place, seeking to speak with the passion of the preacher within me, I found myself stopping short, fearing the potential of my own colonizing impulse. The Christendom of the crusades, the residential schools system, and the holocaust - all disrupt my thought processes. Here I am, the teacher, the one who evaluates and grades, and I am speaking about Christianity from the inside... How can that not but represent colonizing impulses? I didn't know what to do with this. I couldn't find my place, and I needed to take a break. 
I re-grouped and muddled my way to the end. My body felt it all — the fluttering chest, the knotted gut. At least at the end I said something about all that was going on in me, but, even then, I struggled with whether I was losing face or being irresponsible with my power.

At the end of the class I speak from my heart and say something like this.

I need to share with you some of what's been going on within me today as I have sought to represent Christian perspectives. I have been feeling the conflict between the power of my role and the particularity of my faith identity in this classroom. I've been feeling the weight of the colonizing violence of my religion's history. I have been struggling and checking myself on my own inner colonizing impulses, holding myself back from sharing with the full passion that might otherwise be there. Like many of you have shared, it is such a gift that we come together in a space where the particularities of our faith commitments and practice are honoured, celebrated, and shared. What a gift to be among you and learn from and with you. However, as a teacher in this course, as the one with the most power, it feels like it would be much easier to be at a distance from my own particularity, to step back and let someone else lead this class on Christian perspectives. But then I also know that the tension I am experiencing needs to just be what it is. It is not easy sometimes, for all sorts of reasons, and I am trying to realize that is okay too. As such, I want to invite you to share with me, if you are inclined, reflections on your own inner responses to the class today, and I want to thank you for risking, for coming on the journey with me today and hearing me so deeply (placing my hand on my heart) as we take this journey together. Thank you.

I leave the class uncertain as to what has happened, but I feel a dam has broken, again, within me. Tears flow in the privacy of my office.

A month after the course ends, I receive final course evaluations and review all my journal notes from the class. Gathering these together, I write a reflection on my spiritual journey in the class which I share with two of my colleagues-one Muslim, the other Christian - with whom I have been meeting through the semester to process our experiences of our multi-religious program.

As I read through my journal and ponder the experience of the class, having read student reflections on their experiences of the course, I realize how I have been journeying to the cross again and again this semester. For me, the theology of the cross is really more a spirituality for the living of each day, and, in this course, I lived it more close to the core than I have for a while. Working in the shifting spaces of the inter-religious, multi-religious classroom, I continued to find myself following the journey to the cross-struggling and ultimately dying to my compulsions to control, to colonize, to master, and even to synthesize the vast plurality before me. In every class, I confront not only my anxiety to know and to be an expert but also the pedagogical expectations in the academy and the hegemonic epistemologies that marginalize and colonize ways of knowing. As the theology of the cross so poignantly shows, it is only when we die to the impulse to mastery and control-when we surrender our compulsion to colonize and be at the centre of things-it is only then, when we let go and trust that we find ourselves opening to G-d's presence and possibility "hidden" (Luther 1958, pp. 52-54) right there with us. Indeed, how else can I understand the moments of weeping gratitude that peppered through my experience of the class and the students? It is the journey from the compulsion to control and colonize to the experience of humility, gratitude, and awe that marks the theology of the cross and that continued to mark my journey in the classroom.

Further, as I was enabled to walk in a spirit of trust, vulnerability, openness, and humility, so too were the students invited to walk this path with themselves and each other. I believe this path marks an important dimension of our multi-religious classroom that transforms it to an inter-religious community, committed to decolonizing ways of being and learning together. As a class, we gather together and move into new, unknown, and shifting spaces where there is no centre except the one emerging in the moment-a de-colonized space that moves around, centering, decentering, re-centering ... until the space 'with' each other changes us. Previously unseen spaces open up when Jewish, Muslim, Buddhist, Christian, and other students laugh, talk, share, argue, and even weep with each other. It is here that G-d's hidden presence emerges as truth is experienced in glimpses-shifting, hidden, and present. 
At this point, I do think I can say that, whether sitting at the bedside or teaching in a class, the commitment to decolonizing pedagogy and practice in shifting contexts of plurality has much to do with a quality of being - a presence, a humility, an authenticity, a way of 'being with'. In spiritual care literature, we would call this the "use of self" at the heart of what it means to be open, vulnerable, and present. It comes down to trust, to relationships, and to a focused kind of attention that deeply hears, listens to, and is open to be changed by the encounter with others. As a Christian, this journey to decolonizing ways of being opened up for me through an ongoing struggle to the cross and to letting go of my need to master and control. Only then could I be present to the gifts of grace being given in the moment.

\section{Theology of the Cross}

As indicated in my journal entry above, through the process of writing and reflection I recognize, in retrospect, how the theology of the cross informed my pedagogy even as I struggled to find my way. I share now some key elements of the theology of the cross that make it a helpful interpretive framework for lived experience. The theology of the cross was a term coined and given particular content by the Protestant Reformer Martin Luther, but many consider it to be a tradition in Christian practice and thought that extends from its antecedents in the Hebrew Scriptures through the Newer Testament and as a minority tradition within Christianity (McCarroll 2014a, p. 27; Solberg 1997, pp. 55-56; Thompson 2004, pp. 3-28). "Theologia crucis is not a single chapter in theology, but a key signature for" thinking theologically (Moltmann 1974, p. 72; Von Loewenich 1976, p. 27). There are key priorities in the theology of the cross that make it a particularly rich resource for contextually engaged theological reflection on experience, the stuff of practical theology. The theology of the cross places priority on experience, especially experiences of existential struggle, as the starting place for theological reflection. It has a robust critique of power, particularly as it is manifested in privilege, mastery, and control in relation to o/Otherness ${ }^{9}$ and is suspicious of thought and practice that ignores suffering and the messiness of human life and relationships. It privileges experiences of suffering and of limit as spaces where G-d's "hidden presence" (Luther 1958, pp. 52-54) is revealed most authentically, rather than experiences of power, glory, and control, which reflect illusion. Finally, through experiences of limit and suffering, it opens pathways to renewed faith and practice. After outlining these dimensions of the theology of the cross, I will suggest a three-fold process for theological reflection on experience.

\subsection{Priority on Experience}

Contemporary readings of the theology of the cross emphasize the priority of lived human experience in the life of faith. As Luther says, "Experience alone makes a theologian" (Luther 1967, p. 7; Thompson 2004, p. 3). Indeed, the existential struggle to be human is at the heart of this theological frame. Over and against speculative theology (one dimension of what Luther calls theology of glory) or the "ivory tower," as it is more recently called, the theology of the cross attends to the exigencies of what it means to be human, especially as these are played out in daily life and relationships. It is concerned with the concrete and the particular. We must live in the world without illusions in the face of real life-not in abstract ideas of what life is or ought to be (Solberg 1997, p. 83; Thompson 2004, pp. 3-28).

The theology of the cross is not firstly concerned with articulated reflections on experience based on its own frame. Rather, it is most concerned with the actual person of the "theologian," the one who is living the experiences of the cross and the temptations to power and glory (Forde 1997). Indeed, some have suggested that the theology of the cross might well be called "spirituality of the cross" given its focus on the inner and outer dimensions of the spiritual life in the living of each day (Athanasiadis 2008; Maskulak 2008). True theology lives in the thick of things (Solberg 1997, p. 84). Or, as Luther so bluntly states, "Not reading and speculation, but living, dying, and being condemned make a real theologian" (Luther 1960, p. 388). Indeed, as my ethnographic reflection shows, bringing

9 I use "o/Otherness" to indicate other humans, creatures, and G-d. 
the theology of the cross to bear on my own struggles with power, privilege, authenticity, and difference helped to frame and interpret my experience through a theological lens.

In the next Sections 4.2-4.4, I unpack three central movements within the theology of the cross as an interpretive framework. Each of these is evident in my journey to decolonize pedagogy presented above; however, I present them here as an invitation to consider the decolonizing capacity of the theology of the cross for interpreting lived experience.

\subsection{Critique of Power-Critical Move}

The theology of the cross is paradoxical. It stands over and against the theology of glory in all its forms. In its most articulated and critical formulation, it speaks into contexts of power and privilege, rather than to places of oppression. It understands power as control, mastery, domination, and force-the exertion of human will over o/Otherness. Contemporary formulations of the theology of the cross parse out how those with power cause the suffering of those without power. (McCarroll 2014a; Hall 2012) However, the power-over or 'control-power' of the theology of glory is based on a lie-a false conception of what it means to be human and a false understanding of G-d. Rather, the theology of the cross seeks out the "power made perfect in weakness" (2 Corinthians 12:9), known most fully in the cross of Christ.

The first move for the theology of the cross is a critical move, to unmask the ways the theology of glory may be functioning to hide the truth of things. It is concerned with naming how human power, mastery, and privilege distort truthfulness and cause suffering. The theology of the cross is suspicious of all intimations of the theology of glory manifested as they are in power, privilege, control, and mastery in relation to other humans, to knowledge and to things in general. Such power may show itself in everything from expressions of certainty about things that are beyond the power of human reason to know; to relationships of control and domination toward other people(s), the land and creatures; to a denial of suffering and its effects; and so on.

There is an inward and an outward dimension to the critical move of the theology of the cross. First, it presupposes that humans, especially those of us with power and privilege, are masters of self-deception. We seek to maintain our sense of self sufficiency, autonomy, and control partially because the vulnerability of being-in-relation (Hall 1993, pp. 330-34) and being dependent is too much to bear. Also, of course, living in the illusion of the theology of glory feeds our egos and our (false) sense of security as life feels great on our terms with us (and people like us!) at the centre. Thus, for those with relative power, the tendency is to cling to a theology of glory-to 'lie' about ourselves and reality, trusting in our own self sufficiency, and seeking to wield control so as to convince ourselves 'we've got this!'. However, this inward posture is an illusion, a 'lie,' and has outward ethical consequences that are played out in the world and cause more suffering. Indeed, Douglas John Hall has done masterful work in parsing out the ways Western modernity has bought into the lies of the theology of glory-that human identity, meaning, and purpose are shaped by motifs of mastery and control over otherness-and the ways these lies have brought about devastating consequences in creation causing endless suffering through climate change, ecological disaster, and through oppressive ways of engaging otherness (Hall 1993, pp. 253-361; 2003, pp. 92-99). Especially for those with power and privilege, the struggle to live truthfully-acknowledging our incompleteness, limits, and vulnerability—is the beginning of an authentic life before G-d and in creation (Thompson 2004, pp. 67-93). Or, as Luther says, "It is true that man [sic] must utterly despair if his [sic] own ability before he [sic] is prepared to receive the grace of God" (Luther 1958, pp. 40-41).

\subsection{Where Is G-d in This? Suffering and the Cross}

The second move in the theology of the cross involves paying attention to experiences of struggle, suffering, vulnerability, and limit as spaces where the truth of things is most visible and the divine presence may be glimpsed "hidden behind the opposite" (Luther 1958). There is no sense that suffering is redemptive in itself or that we ought to engage in works of suffering to earn credit. No. Rather, 
as Thompson and Solberg eloquently show, the priority placed on suffering in the theology of the cross is descriptive rather than prescriptive (Solberg 1997, p. 69; Thompson 2004, p. 77). The world and each one of us is incomplete, vulnerable, limited, and finite-a reality experienced most poignantly in suffering. Generally, those of us with power and privilege resist the fact of our vulnerability and limit (and capacity to suffer) unless and until life hits us in the face with things we cannot control. This kind of 'suffering,' acknowledging the vulnerability of our finitude, is the truth of things as they are-a description. We can choose to acknowledge this and seek to live out of this reality in relation with all that is, or we can run from it into the theology of glory. The movement from the theology of glory to the theology of the cross is a journey to humility-toward the humus, the dust, the earth from which we came and of which we are made. It is here too that G-d's hidden presence can be glimpsed and we can be awakened to the sheer gift of being and relationship. Humility, gratitude, vulnerability, and trust can all be internal signs of this moment.

\subsection{Constructive Move-How Then Must We Live?}

The third move in the theology of the cross is constructive. Here, the experience of humbling gratitude and trust in the face of the precious vulnerability of life opens up space to live authentically in relation to oneself, with others, with creation and with G-d. A posture of faith as trust rather than anxiety and fear, of openness rather than mastery and control, of gratitude, vulnerability and hope (Reynolds 2008, pp. 139-42) rather than self-sufficiency and autonomy, a "gaze toward G-d and others" rather than on the self (Thompson 2004, p. 27) mark the inner movements of this journey. These dynamics are also manifested in outer ways of living in relationship within the limit and creatureliness of being that have ethical consequences intended to serve life. These include movement from being in the centre to being at the margins, from power to empowerment, from independence to inter-dependent dependence, from individuality to mutuality, and so on.

Through the frame of the theology of the cross, because we are vulnerable, limited, dependent, etc., we never reach a static state of acceptance, living into our true dependent creatureliness in an ongoing way. In fact, the journey from glory to the cross is one that must be lived each day in the big and small details of our lives as we are confronted with the limits and fragility of being. For Luther, the ongoing dialogical and spiritual dimensions of this inner movement are manifested in his privileging of justification as a repeated, even daily, experience of grace in-breaking existentially through the struggle to be human (Thompson 2004, pp. 9-12). It is when we make the journey to the foot of the cross, each day, that we may be opened again to glimpse the beauty of G-d's presence and learn again to receive the gifts of being and of relationships, as the facades of mastery, control, power, and privilege fall away.

\section{Practical Theology of the Cross-Reflective Process for Decolonizing Pedagogy}

From the foregoing discussion and the experience of the course, I would like to suggest that the theology of the cross invites a three-fold practical theological reflective process that both interprets experience and leans toward transformative decolonizing pedagogy. It is a reflective process that tends to both the inner and outer dimensions of power and seeks to re-construct our way of showing up in spaces where we yield power and privilege. The first move is a critical move and asks "what is going on here?" It unpacks ways the theology of glory may be functioning through manifestations of power, control, mastery, and privilege. ${ }^{10}$ Externally, in the multi-religious classroom, it pays attention to who holds power and who does not. Whose voice is being heard and whose is not? Who is taking up space and who is getting 'out of the way'? Who is being served and who is not? It may also analyse how vulnerability, suffering, and limit are being denied or distorted and the consequences

10 This may be done using various social scientific and cultural theories, as well as theology, to help unpack how power is manifesting. 
that follow. Internally, for those of us with power and privilege, as teachers in the multi-religious classroom, this critical move challenges us to face how we are complicit in oppressive or colonizing ways of being in relation. It calls us to be stripped of compulsions for control and to pay attention to the ways our own neediness, fear and limits drive us. Part of this move may include paying attention to how our bodies speak to us, offering wisdom for the journey. In a multi-religious classroom or context, this move interrogates the ways power and privilege seek to manage and structure knowledge, communication and community. It seeks to make visible and to counter all the subtle and often insidious ways the status quo, or so-called normative hegemony, serves colonizing compulsions of power and closes down space for true mutuality and hospitality where all are invited to show up.

The second move asks, "where is G-d in this?" by exploring experiences of vulnerability, suffering, and limit as places where G-d's hidden presence may be glimpsed. Following the call of Matthew 25: 40 that highlights Jesus' presence in the faces of those who are forgotten, imprisoned, ill, and voiceless, we are challenged to pay attention to G-d's presence and possibility with those who suffer, G-d's presence "hidden behind its opposite" (Luther 1958, pp. 52-55). Externally, in the multi-religious classroom, how is space opened up for those whose voices are not being heard? Listening deeply to those who lives have been marked by silencing and suffering, living on the margins of power, is an important practice here. Sometimes, in the multi-religious classroom, this can be uncomfortable as the pressures of conformity and 'efficiency' press in with an impatience that is palpable. However, as teachers, when we can frame and model the practice of listening and making space for all-trusting the process-new voices may be heard and new insights opened up. Internally, for teachers and those with power and privilege, we are invited to show up in a posture of trust and humility-open to be changed by encounters with o/Otherness, receptive to the sometimes unsettling messiness of living encounters and resisting inner compulsions to control and mastery. Indeed, in my own experience of the class, it was when I was freed from the compulsion to control and manage the content of the class, when I bumped up against my limit and vulnerability, that I was opened to perceive the precious gift of G-d's presence in the faces and interactions among the class.

Finally, the theology of the cross asks, "how then must we live?" Externally, this question suggests ways of living interdependently with each other, in dependence on creation and G-d's gift of being. It suggests a vision of human and creaturely flourishing based on inter-relationality with each other and before G-d. What might this look like for how we organize ourselves in classrooms, communities, and societies? What might this look like in contexts of difference and multiplicity? How might such a vision re-order how power is conceived and lived out? In the multi-religious classroom, this includes incorporating concrete practices that support the decolonizing and re-distribution of power such that all members participate, are accountable, and are responsible for the whole. This might include practices such as mutual invitation, whereby members of a class or intercultural gathering invite each other by name to engage in discussion and all are free to pass if not ready to respond when invited. ${ }^{11}$ Internally, while the journey to the cross may be a daily event, there is a paradox in this. Even as we develop habits of being that seek to follow a path to the cross, there is nothing given about this path. It is a narrow path. Indeed, for those of us with power and privilege, we are used to protecting ourselves from acknowledging both our complicity with power and our ultimate vulnerability as creatures. Instead, we usually avoid and resist turning toward the cross until we are confronted by the limits and exigencies of life. At the same time, the journey to the cross is recognized in the walking of it. The more we become acquainted with the cross-as with our own vulnerabilities, incompletion, and limit-the more open we are to the journey itself and to the possibility of meeting G-d there. For those of us who are teachers and leaders in contexts of multiplicity, this internal move toward the cross may include developing means to further concretize reflective practices that empower honest

11 Please see the Kaleidoscope Institute for more information on "mutual invitation" and other excellent practices for empowering intercultural communities and classrooms. http://www.kscopeinstitute.org/. 
engagement with each other and before G-d regarding our own struggles with power and privilege, our vulnerability and our fears, and our stumbling toward humility and trust. Indeed, the exercise of writing this paper, itself, reflects my own stumbling attempt to concretize an inner journey to the cross as a means toward transformed practice.

\section{Conclusions}

In this paper I have explored how the theology of the cross can function as a practical theological interpretive framework and presented it as a reflective process to support decolonizing the multi-religious classroom. I offer it as a resource for decolonizing practice in contexts when Christian power and privilege prevail. The paper suggests a pathway that is drawn from a Christian theological tradition, while also opening up to religious others in a posture of humility, vulnerability, gratitude, and trust. In the complexity of the multi-religious classroom, some may query whether it is appropriate to use a Christian theological frame to interpret and guide action in a multi-religious situation? Clearly, I believe it is appropriate and, indeed, necessary for those who identify as Christian theologians and people of faith. If theology is truly about bringing our lived experiences of faith, conceptions of G-d, sense of vocation, and our religious practices and communities into our study and thought, then it is important to claim resources within particular faith traditions to help enable this, both as an external focus for teaching and as an inner spiritual practice.

Others may query, given the decolonizing movement of the theology of the cross in contexts of power and privilege, is it a helpful or realistic resource in the context of academic learning? Is it merely a means to relinquish responsibility, to abdicate the authority of teacher and to dismiss the importance of content in favour of relational process? Will it lead to a relativism that ultimately leans toward ethical nihilism where nothing is more true than anything else? These are important questions that, again, raise up the messiness and incompletion of creaturely life where, ultimately, no theological framework or interpretive process can have all the answers. Indeed, this reflects the conundrum at the heart of what it means to be human intimated also in the paradoxical character of the theology of the cross. However, at this time when the devastating dimensions of Christendom's reign are being revealed, when Western Christian power and privilege are being challenged and de-centered by voices that speak truth, the theology of the cross offers a resource, a usable past, for decolonizing and transforming Christian practices from within.

Funding: This research received no external funding.

Acknowledgments: I wish to acknowledge my students, from whom I am continuing to learn so much and my colleagues, with whom the journey into unknown territory is dynamic and life-giving. Also, I acknowledge Harris Athanasiadis for his review of this paper prior to submission.

Conflicts of Interest: The author declares no conflict of interest.

\section{References}

Athanasiadis, Harris. 2008. Waiting at the Foot of the Cross: The Spirituality of George Grant. Religious Studies and Theology 27: 231-45. [CrossRef]

Boff, Clodovis. 1998. Methodology of the Theology of Liberation. In Systematic Theology: Perspectives from Liberation Theology. Edited by Jon Sobrino and Ignacio Ellacuria. New York: Orbis Books, pp. 1-21.

Couture, Pamela, McCarroll Pamela, and Nevin Reda. 2019. Shifting, Reforming, Transforming Spaces for a Postcolonial, Interreligious Pedagogy. In Reforming: Space, Body and Politics. Edited by Auli Vähäkangas, Kirstine Helboe Johansen, Tone S. Kaufman and Silvert Angel. Berlin: Lit Verlag, pp. 169-76.

Forde, Gerhardt O. 1997. On Being a Theologian of the Cross: Reflections on the Heidelberg Disputation. Grand Rapids: Eerdmans.

Hall, Douglas John. 1993. Professing the Faith. Minneapolis: Fortress Press.

Hall, Douglas John. 2003. The Cross in our Context: Jesus and the Suffering World. Minneapolis: Fortress Press.

Hall, Douglas John. 2012. Waiting for Gospel. Eugene: Cascade Press.

Kwok, Pui-lan. 2005. Postcolonial Imagination and Feminist Theology. Louisville: Westminster John Knox Press. 
Luther, Martin. 1958. Heidelberg Disputation. In Luther's Works, 31. Edited by Harold J. Grimm. Saint Louis: Concordia Pub., pp. 35-70.

Luther, Martin. 1960. Luther's Works, 34. Edited by Helmut T. Lehmann and Lewis W. Spitz. Saint Louis: Concordia Pub.

Luther, Martin. 1967. Table Talk. In Luther's Works, 54. Edited by Theodore G. Tappert. Saint Louis: Concordia Pub. Maskulak, Marian. 2008. Edith Stein and Simone Weil: Reflections for a Theology and Spirituality of the Cross. Theology Today 64: 445-57. [CrossRef]

McCarroll, Pamela R. 2014a. Waiting at the Foot of the Cross: Toward a Theology of Hope for Today. Eugene: Pickwick.

McCarroll, Pamela R. 2014b. At the End of Hope-The Beginning: Narrative of Hope in the Face of Death and Trauma. Minneapolis: Fortress Press.

Moltmann, Juergen. 1974. The Crucified God. Minneapolis: Fortress Press.

Moschella, Mary Clark. 2018. Practice Matters: New Directions in Ethnography and Qualitative Research. In Pastoral Theology and Care: Critical trajectories in Theory and Practice. Edited by Nancy J Ramsay. West Sussex: Wiley-Blackwell, pp. 5-29.

Reynolds, Thomas E. 2008. Vulnerable Communion: A Theology of Disability and Hospitality. Grand Rapids: Brazos Press.

Solberg, Mary M. 1997. Compelling Knowledge: A Feminist Proposal for an Epistemology of the Cross. Albany: State University of New York Press.

Swinton, John, and Harriet Mowat. 2006. Practical Theology and Qualitative Research. London: SCM Press.

Thompson, Deanna. 2004. Crossing the Divide: Luther, Feminism, and the Cross. Minneapolis: Fortress Press.

Von Loewenich, Walther. 1976. Luther's Theology of the Cross. Translated by Herbert J. A. Bouman. Minneapolis: Fortress Press.

Wall, Sarah. 2008. Easier Said Than Done: Writing an Autoethnography. International Journal of Qualiitative Methods 7: 38-53. [CrossRef]

Welch, Sharon D. 2012. Beyond Theology of Religions: Epistemological and Ethical Challenges of Inter-religious Engagement. In Oxford Handbook of Feminist Theology. Edited by Mary McClintock Fulkerson and Sheila Briggs. Oxford: Oxford University Press.

(C) 2019 by the author. Licensee MDPI, Basel, Switzerland. This article is an open access article distributed under the terms and conditions of the Creative Commons Attribution (CC BY) license (http://creativecommons.org/licenses/by/4.0/). 